\title{
Phytochemical compositions and antimicrobial activity of leaf extracts of Calotropis procera against food spoilage microorganisms
}

\author{
Toheeb D. Yissa', Wahab O. Okunowo ${ }^{1,}$ Rukayat I. Afolayan'2, Abdulakeem R. Agboola3, \\ Halima Y. Lukman ${ }^{4}$, Alfa Suleiman', Abafi J. Majiyebo6
}

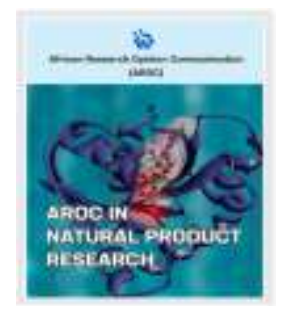

${ }^{1}$ Department of Biochemistry, Faculty of Basic Medical Sciences, College of Medicine, University of Lagos, Akoka-Yaba, Lagos, Nigeria

${ }^{2}$ Department of Medical Laboratory Sciences, Gbagada General Hospital, Lagos State, Nigeria.

${ }^{3}$ Department of Biochemistry, University of Calabar, Calabar Cross-river State Nigeria.

${ }^{4}$ Department of Chemical Sciences, Biochemistry Unit, College of Natural and Applied Sciences, Summit University Offa, PMB 4412, Kwara State, Nigeria

${ }^{5}$ Department of Biological sciences, Federal polytechnic, PMB 55, Bida Niger State

${ }^{6}$ Department of chemical sciences. Federal polytechnic, PMB 55, Bida Niger State

Corresponding author* Toheeb D. Yissa; toheebyissa@gmail.com

Received: 23 November 2021, Revised: 21 December 2021, Published: 08 January 2022

https://doi.org/10.53858/arocnpr01023646

\begin{abstract}
Background: The purpose of this study was to determine the phytochemical composition and antimicrobial potential of crude n-hexane, ethyl-acetate, methanol and aqueous extracts of Calotropis procera leaves against food spoilage microorganisms. Methods: Standard protocols were employed for the analysis of qualitative phytochemical compositions of the extracts, and antimicrobial activities against Staphylococcus aureus, Bacillus cereus, Pseudomonas aerugenosa and Aspergillus niger. Results: Phytochemical analysis revealed the presence of tannin, saponin, alkaloids, flavonoids, reducing sugar and phenolics. Terpenoids were absent in ethyl acetate and n-hexane extracts while cardiac glycoside was absent in all extracts. All extracts produced antimicrobial activity at a varying zone of inhibition. The widest inhibition zone was produced by methanol extract $(21.35 \pm 0.43 \mathrm{~mm})$ on staphylococcus aureus while the lowest inhibition zone $(12.05 \pm 0.45 \mathrm{~mm})$ was observed in the $\mathrm{n}$-hexane fraction. Similarly, the widest inhibition zone $(17.24 \pm 0.95 \mathrm{~mm})$ was produced by methanol on $A$. niger while the lowest inhibition zone $(5.45 \pm 0.42 \mathrm{~mm})$ was produced on $\mathrm{n}$-hexane on $A$. niger. However, the ethyl acetate extract showed no visible inhibitory zone on all the tested microorganisms. The minimum inhibitory concentration ranged from $32 \mathrm{mg} / \mathrm{ml}(S$. aureus and $B$. cereus) for ethanol extracts to $128 \mathrm{mg} / \mathrm{ml}$ ( $B$. cereus, $P$. aerugenosa and $A$. niger) for $\mathrm{n}$-hexane extract. Conclusion: The result shows that the plant is a good source of bioactive compounds that can be used as a natural alternative to a chemical agent in preserving and controlling food poisoning organisms.

Keyword: Antimicrobial; phytochemical; MIC; Calotropis procera; microorganisms; food poisoning.

Citations: Yissa, T.D., Okunowo, W.O., Afolayan, R.I., Agboola, A.R., Lukman, H.Y., Suleiman, A., and Majiyebo, A.J. (2022). Phytochemical compositions and antimicrobial activity of leaf extracts of Calotropis procera against food spoilage microorganisms. AROC in Natural Products Research, $1(2) ; 36-46$, https://doi.org/10.53858/arocnpr01023646
\end{abstract}

\subsection{Introduction}

Food poisoning is considered one of the major causes of diseases and death among people in developing countries $[1,2]$. It has been reported that the yearly losses of global food will reach up to $40 \%$ due to various factors including spoilage by microorganisms [3]. Microorganisms are commonly responsible for the spoilage of large quantities of food and food products [4]. They do these through different mechanisms which include growing on the food, making use of their nutrients and producing metabolites that could cause food spoilage [5].

A prominent number of cases of food poisoning reported were associated with members of Gram-negative bacteria like Salmonella typhi, Escherichia coli and Pseudomonas [6, 7]. Other Gram-positive bacteria including Staphylococcus aureus and Bacillus cereus have 
also been identified as the causative agents of food spoilage [8].

Microorganisms are ubiquitous; therefore, they can easily contaminate food during harvesting, processing, packaging and storing [9]. Also, these microorganisms can withstand adverse conditions used in food preservation such as low temperature, modified atmosphere packaging, vacuum packaging, as well as resist conventional $[10,11]$. Prevention of food spoilage and their etiological agent is traditionally achieved by the use of chemical preservatives $[12,13]$.

Despite the proven efficiency of these chemicals in the prevention and control of food poisoning diseases, their repeated applications have resulted in the accumulation of chemical residues in the food and feed chain, acquisition of microbial resistance to the applied chemicals and unpleasant side effects of these chemicals on human health $[14,15]$. Thus, there is considerable concern among consumers regarding the risk of using chemical additives for human health that led to a reduction in the use of these chemicals in food preservation [16]. Therefore, plants extract has been reported to be an effective natural preservative against spoilage microorganisms due to the presence of several phytochemicals and antioxidant composition [17].

Calotropis procera plant belongs to the family Asclepiadaceae and subfamily of the Apocynaceae which includes over four hundred genera and almost five thousand species distributed throughout the tropics with a very wide range of ecological amplitude. It is a shrub or small tree up to $2.5 \mathrm{~m}$ high, stem usually simple, rarely branched, woody at the base and covered with a fissured, corky bark and branches somewhat succulent [18]. All parts of the plant exude white latex when cut or broken which acts as a defence strategy against insects, viruses and fungi [19].

The plant is commonly found on roadsides, beachfront, dunes and urban areas. Due to its xerophytic nature, it can grow and propagate under harsh desert conditions. It is also grown as an ornamental plant in dry or coastal regions in the world [20]. It is called sodom apple in English; pomme de Sodome in French; tumfafia in Hausa; and ewe bomubomu among Yorubas. In traditional medicine, Calotropis procera has been used to treat common diseases such as fever, rheumatism, indigestion, colds, eczema and diarrhoea. In addition, preparations from latex with honey are used as anti-rabies and also in the treatment of toothache and cough [21]. Leaf extracts and latex of $C$. procera have shown great use as a nematicide in vitro and in vivo [22]. The potentials of $C$. procera leaves in water treatment and its ability to reduce total viable count have also been reported [23].

Numerous reports are available on the antimicrobial potential of Calotropis procera extracts against pathogenic microorganisms but little was known about its preservative effect against spoilage microorganisms, Hence the aim of this study is to determine the phytochemical constituents and antimicrobial potential of leaf extracts of Calotropis procera against food spoilage microorganisms.

\subsection{Materials and Methods}

\section{1 collection and identification of plant material}

The plants were collected from a local farm in Ikorodu, Lagos State, Nigeria. The plant was authenticated at the Botany Department of the University of Lagos, Akoka, Lagos, Nigeria.

\subsection{Test microorganisms and preparation of inoculums:}

The microorganisms used for this study include three bacteria Staphylococcus aureus, Bacillus cereus, Pseudomonas aeroginosa and a fungus Aspergillus niger. All were obtained from the Federal Industrial Institute of Research Oshodi (FIRRO) in Lagos, Nigeria. Fresh bacteria inoculums were pre-cultured in Mueller Hinton broth (MHB) overnight in a rotary shaker at $37^{\circ} \mathrm{C}$. Afterwards, each strain was adjusted at a 
concentration of $10^{8}$ cells $/ \mathrm{ml}$ using 0.5 McFarland standards [24].

The fungal inoculum was prepared from the 48 $h$ culture of fungal isolates in Saboruard dextrose broth (SDB) [25]. The spectrophotometer (A595 $\mathrm{nm}$ ) has been used to adjust the spore density of fungus at a final concentration of $10^{6}$ spores $/ \mathrm{ml}$.

\subsection{Plant preparation, extraction and fractionation}

Extraction and fraction of the $C$. procera leaf were carried out according to Singhal and Kumar method [26]. Briefly, 100 grams of powdered material was soaked in $250 \mathrm{ml}$ each of n-hexane, ethyl acetate, methanol, and distilled water for $24 \mathrm{hrs}$ at room temperature. The extracts were filtered using Whatman filter paper number-1. The filtrates were collected and dried using a rotary evaporator. All extracts were stored at $4^{\circ} \mathrm{C}$. The percentage yield of the fractions was calculated using the formula;

Percentage yield $(\%)=$ dry weight of extract $x 100 /$ dry weight of plant material

\subsection{Phytochemical analysis:}

The qualitative phytochemical (tannin, saponin, alkaloids, flavonoids, steroids, cardiac glycosides, reducing sugar, phenolics terpenoids) screening of the n-hexane, ethyl acetate, methanol, and aqueous leaf extract of $C$. procera was carried out by the method described by Sofowora [27].

\subsection{Determination of Antimicrobial activity of the leaf extracts}

Antimicrobial susceptibility testing was carried using the agar well diffusion method according to the standard of the National Committee for Clinical Laboratory Standards. Briefly, $1 \mathrm{ml}$ aliquot of 18 hrs broth culture that had been adjusted to turbidity equivalent of 0.5 McFarland standards was dispensed into sterile Petri dishes. Molten sterile Muller-Hinton agar was aseptically poured into the plates and gently rotated for the bacteria to be homogenously distributed in the medium. The agar plates were allowed to solidify, after which a sterile cork borer of $9 \mathrm{~mm}$ in diameter was used to cut uniform wells in the agar plates. All plates were incubated at $37^{\circ} \mathrm{C}$ for $48 \mathrm{hrs}$. For the Aspergillus niger, the test was carried out on SDA plates and incubated at $30^{\circ} \mathrm{C}$ for $72 \mathrm{hrs}$. The wells were later filled with $0.5 \mathrm{ml}$ of each of the extracts. In addition, sterile water and DMSO were used as the negative control while Ciprofloxacin and Amphotericin B served as the positive control for bacteria and fungi respectively. The experiment was conducted in triplicates. The clearance zones around the wells were noted and measured in millimetres with a transparent ruler.

\subsection{Minimum inhibitory concentration}

The minimum inhibitory concentration (MIC) is defined as the lowest concentration of the antimicrobial agent that inhibits microbial growth after 24 hrs of incubation. The MIC of the extracts was measured by the agar dilution method as described in previous study [28]. Plant extracts that showed a positive zone of inhibition for the agar well diffusion test were assayed for the determination of MIC. Different concentrations of the effective plant extracts $(0.5,1.0,2.0,4.0,8.0,16.0,32.064 .0,128.0$, $256.0 \mathrm{mg} / \mathrm{ml}$ ) were prepared separately. Five (5 $\mathrm{ml}$ ) of melted Muller Hinton agar was incorporated into $1 \mathrm{ml}$ of each extract, mixed thoroughly to ensure homogeneity. Plates containing only DMSO were used as a control for hexane and methanol extracts while distilled water was used as a control for aqueous extract. An aliquot of $0.1 \mathrm{ml}$ of bacterial culture was inoculated on the surface of agar plates in the form of spots that contained different concentrations of plant extracts. Agar plates were incubated at $37^{\circ} \mathrm{C}$ for $24 \mathrm{hrs}$ and observed for the presence or absence of visible bacterial growth. The MIC was considered as the least concentration of extracts that inhibited the growth of the respective test microorganisms. All assays were carried out in triplicate. 


\subsection{Statistical analysis.}

The experiment was done in triplicate. Values were analyzed using statistical package for social science (SPSS) version 16 and presented as means \pm standard error of the mean. Comparisons between different groups were carried out by one-way analysis of variance (ANOVA) followed by Duncan's Multiple Range Test (DMRT). The level of significance was set at $(p<0.05)$.

\subsection{Results}

\subsection{Percentage yield of leaf extracts of Calotropis procera}

The percentage yield of different solvent fractions of Calotropis procera leaves is

Table 1: Percentag

\begin{tabular}{|l|c|l|}
\hline Solvent & Yield from dry raw powder (g) & Yield (\%) \\
\hline Ethyl-acetate & $15.61 \pm 0.67$ & $7.80 \pm 1.09^{\mathrm{a}}$ \\
\hline n-hexane & $24.60 \pm 0.36$ & $12.30 \pm 1.34^{\mathrm{b}}$ \\
\hline Methanol & $28.21 \pm 0.46$ & $14.10 \pm 0.89^{\mathrm{b}}$ \\
\hline Aqueous & $30.00 \pm 0.23$ & $15.00 \pm 0.45^{\mathrm{b}}$
\end{tabular}

Data are means \pm standard error of the mean of triplicate extractions. Value followed by different superscript alphabet are significantly difference $(p<0.05)$

\begin{tabular}{|c|c|c|c|c|}
\hline Constituents & Ethyl acetate & n-hexane & Methanol & Aqueous \\
\hline Tannin & + & + & + & + \\
\hline Saponin & + & + & + & + \\
\hline Alkaloids & + & + & + & + \\
\hline Flavonoids & + & + & + & + \\
\hline Steroids & + & + & + & + \\
\hline Cardiac glycosides & - & - & - & - \\
\hline Reducing sugar & + & + & + & + \\
\hline Phenolics & + & + & + & + \\
\hline Terpenoids & - & - & + & + \\
\hline
\end{tabular}

\subsection{Antimicrobial activity of ethyl-acetate, n-hexane, methanol and aqueous fractions of Calotropis procera}

The antimicrobial potential of ethyl-acetate, $n$ hexane, methanol and aqueous fractions of Calotropis procera against the food pathogenic microorganisms investigated is shown in table 3 and figure 1 . The results presented in table 1 . The obtained results indicated that the highest yield $(15.00 \pm 0.45 \%)$ was obtained from aqueous extract while the least yield $(7.80 \pm 1.09 \%)$ was obtained from the ethyl-acetate extract.

\subsection{Phytochemical compositions of ethyl- acetate, $\mathbf{n}$-hexane, methanol and aqueous extracts of $C$. procera leaf}

The result of phytochemical screening showed the presence of tannin, saponin, alkaloids, flavonoids, steroids, phenolics, reducing sugar and terpenoids, while terpenoid is absent in both ethyl acetate and $n$-hexane extract and cardiac glycoside is absent in all the extracts (Table 2).

revealed that all extracts produced antimicrobial activity at a varying zone of inhibition. The widest inhibition zone was produced by methanol extract $(21.35 \pm 0.43 \mathrm{~mm})$ on staphylococcus aureus while the lowest inhibition zone $(12.05 \pm 0.45 \mathrm{~mm})$ was observed in the $\mathrm{n}$-hexane fraction. Similarly, the widest inhibition zone $(17.24 \pm 0.95 \mathrm{~mm})$ was produced by methanol on $A$. niger while the lowest inhibition zone $(5.45 \pm 0.42 \mathrm{~mm})$ was produced on n-hexane on $A$. niger. 
Table 3: Diameter of zone of inhibition $(\mathrm{mm})$ of the leaf extracts of $C$. procera against food spoilage microganism

\begin{tabular}{|lccccc|}
\hline Microorganisms & Ethylacetate & n-hexane & Methanol & Aqueous & Control \\
\hline S. aureus & - & $12.05 \pm 0.45$ & $21.35 \pm 0.43$ & $18.03 \pm 0.23$ & $33.04 \pm 0.93$ \\
\hline B. cereus & - & $8.43 \pm 0.73$ & $18.24 \pm 0.23$ & $14.32 \pm 0.43$ & $28.56 \pm 0.84$ \\
\hline P. aeruginosa & - & $7.23 \pm 0.24$ & $15.04 \pm 0.43$ & $12.04 \pm 0.03$ & $25.32 \pm 0.93$ \\
\hline A. niger & - & $5.45 \pm 0.42$ & $17.24 \pm 0.95$ & $14.05 \pm 0.89$ & $30.04 \pm 1.0$ \\
\hline
\end{tabular}

\subsection{Minimum inhibitory concentrations (MIC) of the extracts on tested organisms}

The MIC of $n$-hexane, methanol and aqueous leaf extract of $C$. procera is presented in table 4. For the methanol leaf fraction, the MIC for both $S$. aureus and $B$. cereus was at the concentration of $32 \mathrm{mg} / \mathrm{dl}$, while for $P$. aeruginosa and $A$. niger was $64 \mathrm{mg} / \mathrm{dl}$. Also, the MIC of the aqueous fraction for both $B$. cereus and $A$. niger was $64 \mathrm{mg} / \mathrm{ml}, 32 \mathrm{mg} / \mathrm{ml}$ for $S$. aureus and $128 \mathrm{mg} / \mathrm{ml}$ for $P$. aeruginosa. However, the MIC of the $n$-hexane extract for $S$. aureus was $64 \mathrm{mg} / \mathrm{ml}$ while the MIC for B. cereus, $P$. aeruginosa and $A$. niger was $128 \mathrm{mg} / \mathrm{dl}$.

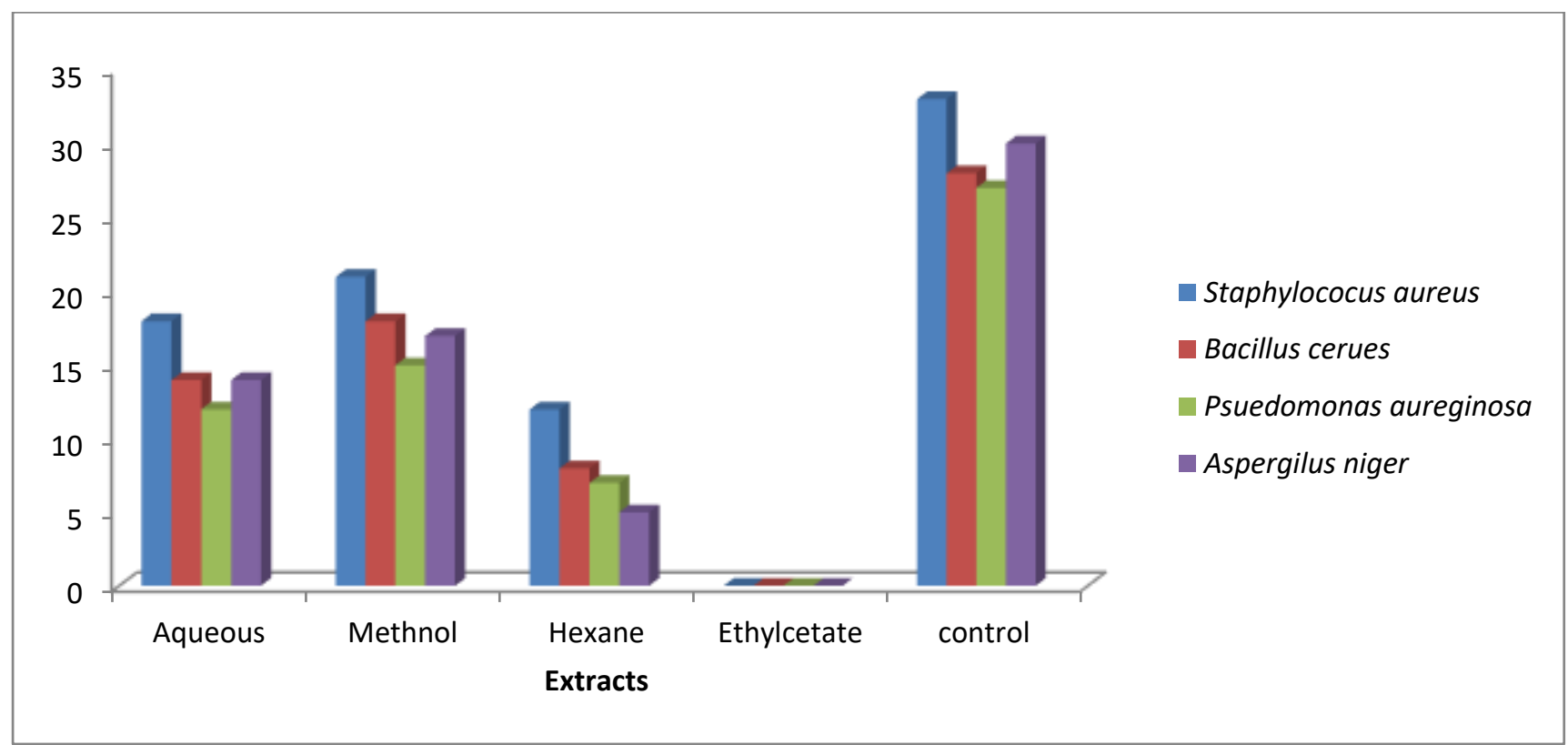

Figure 1. Antimicrobial activity of $C$. procera leaf extracts 
Table 4. Minimum inhibitory concentration of extract $C$. procera leaf on the tested organisms

\begin{tabular}{lcccc}
\hline Test organisms & Concentration $\mathbf{( m g / d I})$ & $\mathbf{n}$-hexane & Methanol Aqueous & Aqus \\
\hline Staphylococcus. Aureus & 16 & + & + & - \\
\hline & 32 & + & - & - \\
\hline Bacillus cereus & 64 & - & - & + \\
\hline & 128 & + & + & - \\
\hline Pseudomonas aeruginosa & 16 & + & - & - \\
\hline & 32 & + & - & + \\
\hline & 128 & + & + & + \\
\hline Aspergilus niger & 16 & + & - & - \\
\hline & 32 & - & - & + \\
\hline
\end{tabular}

Key: + = Growth not inhibited; - = Growth inhibited

\subsection{Discussion}

Solvents of varying polarities were used to maximally extract abundant secondary metabolites from the leaves of $C$. procera and to test the potential of these extracts against pathogenic organisms which are commonly associated with food spoilage. The present study showed that aqueous extract has the highest percentage extraction (15\%) which is somewhat in agreement with the finding of Akindele, [29] which showed that the aqueous extract of $C$. procera has the highest percentage yield of extraction (12.37\%) among the solvents used while on the other hand, the study of Falana [30] indicated that the highest yield $(14.6 \%)$ was obtained from acetone extract and least yield (4.6\%) from the aqueous extract. This may be due to different methods of extraction and solvents used.

The preliminary phytochemical investigation revealed that $C$. procera extracts contain many secondary metabolites as shown in table 2 . This shows that extracts can attract many compounds which have the potential to be used as a preservative agent. This result is somewhat in agreement with the findings of the previous studies that used only ethanol and aqueous solvents [31]. Phytochemicals have been reported to inhibit microbial growth [32].
Tannins have been reported to have antibacterial potential due to their basic character that allows them to react with proteins to form stable water-soluble compounds thereby killing the bacteria by directly damaging its cell membrane [33]. Similarly, Saponin is known to have expectorant activity were observed in the plant. The antibacterial activities of alkaloids and flavonoids have been reported by a number of authors [34, 35]. The presence of these phytochemical constituents may be responsible for the antimicrobial and preservative potentials of this plant.

The antimicrobial results showed that the extracts have varying degrees of antimicrobial activities against the tested organisms. In this study, the antimicrobial activity of $C$. procera leaf extracts suggested that Staphylococcus aureus was the most susceptible strain followed by Bacillus cereus, $A$. niger and $P$. aureginosa respectively. According to this observation, it was methanol, aqueous and $\mathrm{n}$-hexane extracts that showed antimicrobial activities in comparison to ethyl acetate extract which showed no effect on any of the tested organisms. This result is in conformity with the findings of Salem et al., [36] who found that $C$. procera leaf extract has the highest activity on Staphylococcus aureus 
among the tested microorganisms. The results also followed the findings of the previous studies $[37,38,39]$. Most of these studies proved that both organic and aqueous extracts have antimicrobial efficacy against spoilage microorganisms. Olukoya [40] proved that ethanol extract was greatly more potent against the spoilage organisms than the organic extract while Egwari [41] on the other hand indicated that organic extract was more effective against microorganisms than the corresponding aqueous extracts of the same concentration. The present work is also against the study of Akin-Osanaiye et al., [42] who found that ethanol extract is the most sensitive to the tested organisms than the methanol and aqueous extracts as against what was observed in this study. This may be due to the extraction of more bioactive compounds by the organic solvent and greater diffusibility of the organic solvents in the media than the aqueous extracts [41].

The control drugs (Ciprofloxacin and Amphotericin B) showed higher zones of inhibition on the test organisms than the plant extracts. Doughari et al., [43] reported that the state of administration of an antimicrobial agent affects the effectiveness of such agent and that antibiotics being in a refined state and plant extracts in the crude state, may record higher antimicrobial activity. Also, the small molecular size possessed by antibiotics as reported by Maillard [44] aids their solubility in diluents as this could enhance their penetration through the cell wall into the cytoplasm of the organisms.

The MIC values reported in the present study were higher than what was reported (5.0 - 10.5 $\mathrm{mg} / \mathrm{ml}$ ) by Shobowale and Olatope, [45], Nenaah and Ahmed, who reported MIC of the methanolic extract of the leaf to be $0.25-1.25$ $\mathrm{mg} / \mathrm{ml}$ but lower than the finding of AkinOsanaiye et al., [42] in which the extracts having a MIC value of $125 \mathrm{mg} / \mathrm{ml}$ and above. Doughari et al., [43] reported that high MIC may be an indication of low efficacy or that the organisms have the potential for developing resistance to the bioactive compounds and low
MIC is a good indication of high efficacy against these organisms as established in the present study in which the MIC value is between $32-128$ $\mathrm{mg} / \mathrm{ml}$.

The inhibition of bacterial strains ( $S$. aureus, cereus \& $P$. aeruginosa) suggests that the plant extract possesses broad-spectrum antibacterial properties, which could be used in the treatment of diseases and food poisoning, in which these pathogens are often implicated [46, 47]. The phytochemical compositions of the plant extracts could have exhibited antimicrobial activities via inhibition of the hydrolytic enzymes (proteases), microbial adhesion, and cell envelope transport proteins $[48,49]$. However, future mechanistic studies are required to ascertain these assumptions.

\subsection{Conclusion}

In conclusion, the results of the present study revealed that the leaf extracts of Calotropis. procera has antimicrobial activity against tested food spoilage microorganisms. The bioactive compounds from the plant if purify and concentrated, may be used as a suitable natural alternative in preventing food poisoning, preserving foodstuffs, and avoiding health hazards of chemically antimicrobial agent applications.

Ethics approval and consent to participate: Not applicable

Availability of data and material: Not applicable

Competing interests: The authors declared no conflict of interest exist

Funding: This is a self-sponsored research work

-Authors' contributions: All authors participate in the study. All authors read and approved the final manuscript. 


\section{Reference}

1. Pirbalouti, A. G., Chaleshtori, A. R., Tajbakhsh, E., Momtaz, H., Rahimi, E., \& Shahin, F. (2009). Bioactivity of medicinal plant extracts against Listeria monocytogenes isolated from food. J Food Agric Environ, 7, 66-9.

2. Sapkota, R., Dasgupta, R., \& Rawat, D. S. (2012). Antibacterial effects of plants extracts on human microbial pathogens \& microbial limit tests. International journal of research in pharmacy and chemistry, 2(4), 926-936.

3. Joint, F. A. O., WHO Expert Committee on Food Additives, \& World Health Organization. (2011). Safety evaluation of certain contaminants in food: prepared by the Seventy-second meeting of the Joint FAO/WHO Expert Committee on Food Additives (JECFA). World Health Organization.

4. Lianou, A., Panagou, E. Z., \& Nychas, G. J. (2016). Microbiological spoilage of foods and beverages. In The stability and shelf life of food (pp. 3-42). Woodhead Publishing.

5. Parlapani F. F., Mallouchos A., Haroutounian S. A., Boziaris I. S. (2017). Volatile organic compounds of microbial and non-microbial origin produced on model fish substrate uninoculated and inoculated with gilt-head sea bream spoilage bacteria. LWT Food Sci. Technol. 78 54-62.

6. Solomakos, N., Govaris, A., Koidis, P., Botsoglou, N. ( 2008). The antimicrobial effect of thyme essential oil, nisin and their combination against Escherichia coli 0157: $\mathrm{H} 7$ in minced beef during refrigerated storage. Meat Sci. 80, 159-166.

7. Pandey, A., and Singh, P. (2011). Antibacterial activity of Syzygium aromaticum (Clove) with metal ion effect against food borne pathogens. Asian J. Plant Sci. Res. 1 (2), 69-80.

8. Braga, L.C., Shupp, J.W., Cummings, C., Jett, M., Takahashi, J.A., Carmo, L.S., (2005). Pomegranate extract inhibits Staphylococcus aureus growth and subsequent enterotoxin production. J. Ethnopharmacol. 96, 335-339.

9. Hatab, S., Athanasio, R., Holley, R., RodasGonzalez, A., and Narvaez-Bravo, C. (2016). Survival and reduction of shiga toxin-producing Escherichia coli in a fresh cold-pressed juice treated with antimicrobial plant extracts. J. Food Sci. 81, 1987-1995. doi: 10.1111/17503841.13382

10. Saraiva, C., Fontes, M. D. C., Patarata, L., Martins, C., Cadavez, V., and GonzalesBarron, U. (2016). Modelling the fate of Listeria monocytogenes in beef meat stored at refrigeration temperatures under different packaging conditions. Proc. Food Sci. 7, 177-180. doi: 10.1016/j.profoo.2016.10.002

11. Säde, E., Penttinen, K., Björkroth, J., and Hultman, J. (2017). Exploring lot-to-lot variation in spoilage bacterial communities on commercial modified atmosphere packaged beef. Food Microbiol. 62, 147152. doi: $10.1016 /$ j.fm.2016.10.004

12. Yamamura, A., Murai, A., Takamatsu, H., Watabe, K. (2000). Antimicrobial effect of chemical preservatives on enterohemorrhagic Escherichia coli 0157: H7. J. Health Sci. 46, 204-208.

13. Shan, B., Cai, Y., Brooks, J. D., and Corke, $H$. (2007). The in vitro antibacterial activity of dietary spice and medicinal herb extracts. Int. J. Food Microbiol. 117, 112119.

14. Akinyemi, K.O., Oluwa, O.K. and Omomigbehin, E.O.(2006). Antimicrobial activity of crude extracts of three medicinal 
plants used in South-West Nigerian folk medicine on some food borne bacterial pathogens. Afr. J. Trad. Compl.Altern. Med. 3 (4), 13-22.

15. Bialonska, D., Ramnani, P., Kasimsetty, S. G., Muntha, K. R., Gibson, G. R., \& Ferreira, D. (2010). The influence of pomegranate by-product and punicalagins on selected groups of human intestinal microbiota. International journal of food microbiology, 140(2-3), 175-182.

16. Kalem, I. K., Bhat, Z. F., Kumar, S., and Desai, A. (2017). Terminalia arjuna: a novel natural preservative for improved lipid oxidative stability and storage quality of muscle foods. Food Sci. Hum. Wellness 6, 167-175. doi: 10.1016/j.fshw.2017.08.001

17. Clarke, D., Tyuftin, A. A., Cruz-Romero, M. C., Bolton, D., Fanning, S., Pankaj, S. K., et al. (2017). Surface attachment of active antimicrobial coatings onto conventional plastic-based laminates and performance assessment of these materials on the storage life of vacuum-packaged beef subprimals. Food Microbiol. 62, 196-201. doi: 10.1016/j.fm.2016.10.022

18. Orwa C, A Mutua, Kindt R , Jamnadass R, S Anthony. 2009 Agroforestree Database:a tree reference and selection guide version 4.0

(http://www.worldagroforestry.org/sites/t reedbs/treedatabases.asp)

19. DEEPAK D. (1995) Phytochemistry of Indian Asclepiadaceae. In: The Taxonomy and Phytochemistry of the Asclepidaceae in Tropical Asia,Kiew, R. (Ed.). University Pertanian, Malaysia 33-44.

20. Ahmed, K. K., Mueen, A. C., Rana, B. and Dixit. V. K. (2005). "Calotropis Species (Ascelpediaceace)-A Comprehensive Review." Pharmacognosy Magazine 1, no. 2: 48 .
21. Kew, F. (1985): The useful plants of West Tropical Africa, Vol. (1). Families A - D Edition 2 (ed Burkill, H. M.). Royal Botanical Gardens. Pp.219-222.

22. Khirstova, P. and Tissot, M. (1995). Soda Anthroquinone pulping of Hibiscus Sabdariffa (Karkadeh) and Calotropis procera from Sudan. Bioresource Technology. 53: 677-72.

23. Shittu, B. O.; Popoola, T. O. S. And Taiwo, O. (2004): Potentials of Calotropis procera leaves for Wastewater treatment. Proceedings of the International Conference on Science and National Development held at University of Agriculture, Abeokuta. Pp.97-101.

24. Perilla, M. J., (2003). Manual for the laboratory identification and antimicrobial susceptibility testing of bacterial pathogens of public health importance in this developing world".WHO.209-214.

25. Nisha, M. C., Subramanian, M. S., Prathyusha, P., and Santhanakrishnan, R. (2010). Comparative studies on antimicrobial activity of Artemisia sieversiana Ehrhart. Ex. Willd. and Origanum vuigare L. Int. J. Pharmtech Res. 2, 1124-1127.

26. Sighal, A. and Kumar, V. L. (2009). Effects of aqeous suspension of dried latex of Calotropis procera on hepatorenal functions in rat.Journal of Ethnopharmacology 122: 172 - 174.

27. Sofowora, E. A. (1984). Medicinal and Traditional Medicine in Africa. John Wiley and Sons, London. 249.

28. Yusuf, A. A., Lawal, B., Yusuf, M. A., Adejoke, A. O., Raji, F. H., \& Wenawo, D. L. (2018). Free radical scavenging, antimicrobial activities and effect of subacute exposure to Nigerian Xylopia Aethiopica seed extract on liver and kidney 
functional indices of albino rat. Iranian journal of toxicology, 12(3), 51-58.

29. Akindele, P. O., Fatunla, O. A., Ibrahim, K. A., \& Afolayan, C. O. (2017). Antibacterial and phytochemical screening of Calotropis procera leaf extracts against vancomycin and methicillin resistant bacteria isolated from wound samples in hospital patients. Journal of Complementary and alternative Medical Research, 1-14.

30. Falana, M. B., \& Nurudeen, Q. O. (2020). Evaluation of phytochemical constituents and in vitro antimicrobial activities of leaves extracts of Calotropis procera against certain human pathogens. Notulae Scientia Biologicae, 12(2), 208- 221.

31. Kawo, A. H., Mustapha, A., Abdullahi, B. A., Rogo, L. D., Gaiya, Z. A., Kumurya AS (2009).Phytochemical properties and antibacterial activities of the leaf and latex extracts of Calotropis procera (Ait.F.). Bayero Journal of Pure and Applied Sciences;2(1): 34-40.

32. Umar, S. I., Lawal, B., Mohammed, B. A., Obiekezie, C. I., Adewuyi, A. H., Babalola, S. B., \& Ariyeloye, S. D. (2019). Antioxidant and antimicrobial activities of naturally occurring flavonoids from $M$. heterophylla and the safety evaluation in Wistar rats. Iranian Journal of Toxicology, 13(4), 39-44.

33. Elmarie, V. W. and Jonah, C.P. (2001).Purification and identification of active antibacterial component in Carpobrotus edulis L. Journal of Ethnopharmacol. 76: 87-91.

34. Aliero, A. A., Aliero, B. L. and Buhari, U. (2008). Preliminary Phytochemical and Antibacterial screening of Scadoxus maltiflorus, International Journal of Pure and Applied Sciences. 2(4); 13- 17
35. Yesmin, M.N., Uddin, N.S., Sanzida, M., and Muhammad, A. A. (2008). Antioxidant and Antibacterial Activities of Calo-tropis procera.American-Eurasian Journal of Agric and En-vironmental Science. 4 (5): 550-553

36. Salem w. m., sayed .w.f., haridy, m, and Hassan , n.h. antibacterial activity of calotropis procera and ficus sycomorus extracts on some pathogenic microorganisms. African journal of biotechnology. Volume 13(32), pp. 32713280.

37. Nennah, G. and Essam, A. (2011).Antimicrobial activity of extracts and latex of Calotropis procera (Ait) and synergestic effect with reference antimicrobials. Res J. Med. Plants 5:706716

38. Hassan, S. W., Bilbis, F. L, Ladan, M. J., Umar, R. A. and Dangoggo, S. M. (2006). Evaluation of antifungal activity and phytochemical analysis of leaves, roots and stem barks extracts of Calotropis procera (Asclepiadaceae). Pak J Biol Sci; 9(14):2624-9.

39. Kareem, S. O., Akpan I., and Ojo., O. P, (2008). Antimicrobial activities of calotropis procera on selected pathogenic microorganisms. Afr. J. Biomed. Res., 11: 105-110.

40. Olukoya, D. K and Akinsinde, K. A (1995). Vibriocidal activities of some Local herbs. J. Diarrhoeal Dis. Res. 14(4) 283-285

41. Egwari L.O. (1999): Antibacterial Activity of Crude Extract of Nauclea latifolia and Eugenia aromatica. West African Journal of Drug Research. 15 (1\&2): 55 - 59.

42. Akin-Osaneme., Bukola Catherine and Okhomina Lucky. Phytochemical and anibacteria activity of leaf extracts of calotropis procera on some Selected Bacteria. Direct Research Journal of 
Biology and Biotechnology. Vol. 4 (2), pp. 16-21.

43. Doughari, J., and Pukuma, M (200).Antibacterial effects of Balanites aegyptiaca L. Drel.And Moringa oleifera Lam. on Salmonella typhi.African Journal of Biotechnology; 6(19):2212-2215.

44. Mailard, J. Y. (2002). Bacterial target sites for biocide action. Journal of Applied Microbiology ;9:16-27.

45. Shobowale, O. O., Ogbulie, N. J., Itoandon, E. E., Oresegun, M. O., \& Olatope, S. O. A. (2013). Phytochemical and antimicrobial evaluation of aqueous and organic extracts of Calotropis procera ait leaf and latex. Nigerian Food Journal, 31(1), 77-82.

46. Yusuf, A. A., Lawal, B., Abubakar, A. N., Berinyuy, E. B., Omonije, Y. O., Umar, S. I., .. \& Alhaji, Y. M. (2018). In-vitro antioxidants, antimicrobial and toxicological evaluation of Nigerian Zingiber officinale. Clinical Phytoscience, 4(1), 1-8.

47. Tsado, N. A., Lawal, B., Kontagora, G. N., Muhammad, B. M., Yahaya, M. A., Gboke, J. A., ... \& Hassan, M. K. (2016). Antioxidants and antimicrobial-activities of methanol leaf extract of senna occidentalis. Journal of Advances in Medical and Pharmaceutical Sciences, 1-7.

48. Tsado, N. A., Lawal, B., Kontagora, G. N., Muhammad, B. M., Yahaya, M. A., Gboke, J. A., ... \& Hassan, M. K. (2016). Antioxidants and antimicrobial-activities of methanol leaf extract of senna occidentalis. Journal of Advances in Medical and Pharmaceutical Sciences, 1-7.

49. Ibrahim, A. M., Lawal, B., Abubakar, A. N., Tsado, N. A., Kontagora, G. N., Gboke, J. A., \& Berinyuy, E. B. (2017). Antimicrobial and free radical scavenging potentials of $\mathrm{N}$ hexane and ethyl acetate fractions of Phyllanthus Fraternus. Nigerian Journal of Basic and Applied Sciences, 25(2), 6-11.
Submit your article to AROC JOURNALS

-AROC in Pharmaceutical and Biotechnology

-AROC in Agriculture

-AROC in Food and Nutrition

-AROC in Natural Product Research

-BIOMED Natural and Applied Science

Visit: https://arocjournal.com/

Copyright (c) 2022 Yissa et al. This is an open access article distributed under the terms and conditions of the Creative Commons Attribution License (https://creativecommons.org/licenses/by/4.0/)

AROC in Natural Products Research, 2022, 1(2):36-46 https://doi.org/10.53858/arocnpr01023646 ISSN: 2789-391X 